guilty verdict. Brown was undoubtedly doomed from the start, but McGinty demonstrates how the abolitionist was repeatedly short-changed, especially due to the haste with which he was brought to trial. Largely stifled in his ability to obtain the kind of representation he sought, the same haste also undercut the highly qualified attorneys who finally made it to his side in the last hours of his short but well-publicized trial.

Notwithstanding his having been rushed to judgment, the reader shares McGinty's closing impression that John Brown, however imperfectly, made the best possible use of his trial in the end. In a kind of inspired declaration, Brown's address to the court (which McGinty identifies as a "remarkable" allocution) was the real moral climax of the trial (226). "Viewed in the long lens of history," the author concludes, "it is clear that John Brown was not really on trial in Charlestown" because "[he] turned the accusation against him into an accusation against slavery" (287). For the first time, in Jobn Brown's Trial, we are given a front row view of Brown the prisoner - not as a victim, but as a thoughtful if not frustrated defendant, coming to terms with the limitations of justice for himself as well as the slave. Brown is rushed to the gallows, but not before turning his own judgment back upon his accusers, many of whom would shortly lose life, home, and treasure by rushing themselves into a treasonous war against the federal government.

Louis A. DeCaro Jr.

Alliance Theological Seminary

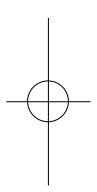

Carole Boyce Davies, Left of Karl Marx: The Political Life of Black Communist Claudia Jones (Durham: Duke University Press, 2008).

Claudia Jones contributed enormously to the American and British Left, but was subsequently lost in the historical narrative of American political radicalism for a number of reasons. First, Jones was a devout Marxist and member of the American and later British Communist Party who was deported at the height of anti-Communist hysteria. Second, she was a woman in largely male organizations. And finally, as a black West Indian living in the United States and England, she experienced the rampant racism and nativism within the Left as well as society. In her new biography of Jones, Left of Karl Marx, Carole Boyce Davies argues that when Jones was deported, the "radical black female subject" in the American Left was silenced as well (2). Jones embraced her identity and through her experience expounded on and eventually popularized the understanding that a black woman faced triple oppression. This idea, later adopted by black American feminists in the 1970s, most notably in the "Combahee River Collective Statement," arguably should place Jones firmly in the history of feminism and the Left. This is precisely what Davies accomplishes in her text. 
Davies' title describes both the ideological position of Jones as Left of traditional Marxist ideology and her literal burial place left of Karl Marx in Highland cemetery in London, England. 'Tracing Jones' prolific writing career from her early years in the CPUSA, her prison poetry and writing, and even the FBI files on her, Davies offers an intellectual biography of an important American Communist and feminist thinker. Davies concludes that Jones combined Marxism with decolonization and gender and class subordination to formulate an understanding of the "superexploitation" of black women (2). Jones' integration of both gender and race oppression within her Marxist practice placed her further Left of Karl Marx because traditional Marxism failed to account for either gender or race. Jones synthesized black women's superexploitation within the CPUSA's Marxist-Leninist position. Davies examines some of Jones' most influential writing within the Party including her 1949 article "An End to the Neglect of the Problems of the Negro Women!" In this and other articles Jones outlined the core of her belief that black women's emancipation had to come first in order for any woman to be free. Davies explains that Jones highly controversial idea that race was "prior to" gender put her at odds with the white Left (48).

Davies also explores Jones' intellectual production and reflections during her incarceration while awaiting deportation. Jones enjoyed an intimate relationship with fellow communist Elizabeth Gurley Flynn during the deportation proceedings. The two women frequently wrote about the injustices of their trials and formed a bond that would only be broken by their deaths within months of each other in 1964. Davies intimates that Jones also believed that her eventual deportation, despite her ill health, was evidence of the precarious citizenship of black people everywhere.

Jones is also unique because of her transnational identity as a West Indian immigrant to the United States. Eventually her radical political position led to a second migration to England, after her 1955 deportation, where Jones' participated in the diasporic politics of London's Afro-Caribbean community. Here Davies argues that Jones used the medium of journalism to outline her anti-imperialism and her belief that global capitalism perpetuated the continued exploitation of black labour globally. Prompted by riots in Notting Hill in 1958 and the 1959 murder of Caribbean immigrant Kelso Cochrane, Jones increased her political activity engaging in anti-racist work in London, writing for the West Indian Gazette and Afro Asian Caribbean News and creating the London Carnival celebration. Eventually her diasporic politics would cut into her work for the British Communist Party leading it to reprimand her several times. Nevertheless, Davies notes that Jones' would spend the remainder of her short life formulating cultural and political expressions of black people's freedom and self-determination all the while remaining devoted to the communist class analysis of oppression. 
Davies, however, does not offer a complete biographical sketch of Jones. Instead her interest is primarily in tracing Jones' intellectual evolution through her vast writings. While Davies recognizes the intimacy of Jones' writing and her understanding of her own subject-position as primary in her political cosmology, there is no more than passing mention of Jones' early life in Trinidad, her immigration to the United States, and her family life in Harlem. Ultimately, this however is not Davies' goal. She is first and foremost explicating the radical political position of an important Left-wing ideologue. Davies successfully establishes Jones' place in the Left historical canon as a leading black feminist thinker in a text that is a long overdue treatment of an Old Left woman whose influence on the New Left is only now coming to light.

Denise Lynn

University of Southern Indiana

\section{Frank Kusch, Battleground Chicago (Chicago: University of Chicago Press, 2008).}

The 1968 battle between police and anti-war demonstrators at the Democratic National Convention in Chicago has become a pivotal event in the history of the 1960s, signalling the implosion of the Democratic party, the souring of sixties activism, and the fracturing of the New Deal coalition. The popular obsession with what Canadian writer and editor Frank Kusch calls "Battleground Chicago," implicitly confirms the belief that working-class white backlash against black and antiwar radicalism was the source of this implosion. As Kusch demonstrates, however, the actual sequence of events and police behaviour therein offers a somewhat different perspective than the common view of Chicago as a "police riot" by cops who went berserk in the streets.

As Kusch notes in his preface, he aims to move beyond the stereotypes of Chicago cops as "pigs" and "storm troopers," showing them instead "as they saw themselves - men with families, mortgages, and lives" (x). His extensive interviews with Chicago police veterans provides a valuable window in to the social, cultural, and political attitudes of some of these key participants. Viewing the Vietnam war and the wrenching changes of the era from Chicago's Bungalow Belt, many police believed they had to defend the city from outsiders, be they African Americans moving into their neighbourhoods or scruffy hippies and protesters bent on dishonouring the country. Stung by criticism of his handling of the April riots following the assassination of Martin Luther King, Jr., Mayor Richard Daley gave police the license they needed to fight off and often physically punish anti-war demonstrators in the streets of Chicago that August. The three chapters covering the convention are a riveting read. Kusch provides a blow-by-blow account (literally) from the ruthless clearing of demon- 